\title{
Improved Sampling in Carrier-Based Discountinuous SVPWM Simulation
}

\section{Peningkatan Sampling pada Simulasi SVPWM Discountinuous Berbasis Pembawa}

\author{
Okik Surikno $^{1}$, Tole Sutikno ${ }^{2}$ \\ ${ }^{1}$ Mahasiswa Program Studi Teknik Elektro, Universitas Ahmad Dahlan, Indonesia \\ ${ }^{2}$ Dosen Program Studi Teknik Elektro, Universitas Ahmad Dahlan, Indonesia
}

\section{INFORMASI ARTIKEL}

Riwayat Artikel:

Dikirimkan 14 Februari 2020,

Direvisi 28 September 2020,

Diterima 28 September 2020.

\section{Kata Kunci:}

SVPWM,

Discontinuous,

Sinyal referensi,

Sampling,

FPGA,

Quartus II.

\section{Penulis Korespondensi:}

Okik Surikno, Tole Sutikno Universitas Ahmad Dahlan Kampus 4 UAD, Jln. Ring Road Selatan, Tamanan, Banguntapan, D.I. Yogyakarta, Indonesia.

Surel/Email:

okiksurikno02@gmail.com tole@ee.uad.ac.id

\begin{abstract}
ABSTRAK
In this study, a circuit was designed to improve sampling in discontinuous SVPWM simulations using Quartus II software. The v_beta_sin unit was successfully simulated using the waveform editor. The results displayed are in accordance with previous calculations, if the input is 000000001 then the output is 100000011 and so on. The v_alfa_cos unit is also successfully simulated using the waveform editor. The simulation results if the input is 000000001 then the output is 111111111 and so on, according to the previous calculation. The unit counter was successfully simulated using the block diagram in Quartus II. The output of this unit counter is in the form of 9 bits to retrieve v_beta_sin and v_alfa_cos data. The v_beta_sin, v_alfa_cos and counter units used as reference signals are successfully simulated and can be used as a supporting circuit in the simulation of the discontinuous SVPWM method. The results of the simulation show an increase in sampling or sampling by 512 .
\end{abstract}

Pada penelitian ini dirancang rangkaian untuk meningkatkan sampling pada simulasi SVPWM discontinuous dengan menggunakan perangkat lunak Quartus II. Unit v_beta_sin berhasil di simulasikan menggunakan waveform editor. Hasil yang ditampilkan sesuai dengan perhitungan sebelumnya, jika inputannya 000000001 maka outputnya 100000011 dan seterusnya. Unit v_alfa_cos juga berhasil di simulasikan menggunakan waveform editor. Hasil simulasinya jika inputnya 000000001 maka outputnya 111111111 dan seterusnya, sesuai dengan perhitungan sebelumnya. Unit counter berhasil di simulasikan menggunakan diagram blok pada Quartus II. Keluaran dari unit counter ini berupa cacahan 9 bit untuk mengambil data v_beta_sin dan v_alfa_cos. Unit v_beta_sin, v_alfa_cos dan counter yang digunakan sebagai Sinyal referensi berhasil disimulasikan dan dapat digunakan sebagai rangkaian pendukung pada simulasi metode SVPWM discontinuous. Hasil dari simulasi menunjukkan peningkatan sampling atau pencuplikan sebesar 512 .

This work is licensed under a Creative Commons Attribution-Share Alike 4.0

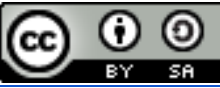

\section{Sitasi Dokumen ini:}

Okik Surikno and Tole Sutikno, "Improved Sampling in Carrier-Based Discountinuous SVPWM Simulation," Buletin Ilmiah Sarjana Teknik Elektro, vol. 2, no. 3, pp. 137-144, 2020. DOI: 10.12928/biste.v2i3.1753 


\section{PENDAHULUAN}

Teknik modulasi SPWM adalah teknik modulasi dengan membandingkan antara gelombang sinusoida sebagai sinyal referensi dan gelombang segitiga sebagai sinyal pembawa untuk memperoleh sinyal PWM yang digunakan pada pada proses switching [1]. Dasar dari metode SVPWM (Space Vector Pulse Width Modulation) berbeda dengan metode SPWM (Sinusoidal Pulse Width Modulation). SVPWM bertujuan untuk mencapai bentuk gelombang tegangan sinus tiga fase dari tegangan dan frekuensi yang dapat disesuaikan, sementara SVPWM menggunakan inverter dan motor secara keseluruhan menggunakan delapan tegangan vektor untuk mendapatkan frekuensi, tegangan dan kecepatan [2].

Dalam teknik modulasi persyaratan yang penting adalah mendapatkan output daya yang lebih tinggi dan efisien untuk berbagai kontrol tegangan keluaran inverter [3]. Metode Space Vector Pulse Width Modulation (SVPWM) merupakan metode yang terbaik di antara semua teknik PWM dalam penerapan drive frekuensi variabel, SVPWM lebih fleksibel serta mudah diimplementasikan dengan DSP (Digital Signal Processing) atau FPGA (Field Programmable Gate Array [4] dan[5]. Fleksibilitas ini didasari dengan SVPWM yang hanya membutuhkan tegangan referensi tunggal daripada tiga referensi tegangan yang diperlukan dalam SPWM, dan tegangan inventer output dalam SVPWM dapat secara bertahap dikendalikan dari PWM ke mode six step. Selain itu dibandingkan dengan metode SPWM, Metode SVPWM lebih unggul dalam banyak aspek yaitu indeks modulasi lebih tinggi, tegangan output $15 \%$ lebih tinggi, serta harmonik arus dan torsi yang dihasilkan jauh lebih sedikit [6].

Ada 2 Metode SVPWM yang sudah banyak diimplementasikan, yaitu metode SVPWM continuous dan SVPWM discontinuous. SVPWM continuous memiliki kekurangan seperti beban komputasi yang tinggi, kinerja yang lebih rendah pada indeks modulasi tinggi dan kerugian switching inverter yang tinggi. Jadi untuk mengurangi kerugian switching yang tinggi dan meningkatkan kinerja di daerah indeks modulasi tinggi, maka dalam penelitian ini akan menggunakan metode SVPWM discontinuous.

SVPWM discontinuous adalah teknik modulasi yang menawarkan kerugian switching yang lebih rendah dan algoritma yang lebih sederhana dibandingkan dengan SVPWM continuous [7]. Pada saat yang sama, frekuensi switching rata-rata, atau frekuensi switching 1,5 kali lebih tinggi daripada yang digunakan dalam SVPWM continuous, SVPWM discontinuous menghasilkan distorsi harmonik arus yang lebih rendah daripada yang diperoleh dalam SVPWM continuous pada indeks modulasi tinggi [8] dan [9]. Metode SVPWM discontinuous menggunakan enam vector ruang aktif [10]. Keenam vector aktif tersebut menghasilkan tegangan output sinusoidal dan harmonik arus rendah. Dalam penelitian ini akan memverifikasi metode yang disederhanakan dan mendefinisikan sektor vektor tegangan ruang. Ini akan menunjukkan bahwa pendekatan sederhana untuk merancang SVPWM discontinuous menghasilkan kecepatan tinggi dalam komputasi keseluruhan algoritma sehingga menghasilkan frekuensi switching yang tinggi dan distorsi harmonik arus yang rendah dalam sistem penggerak motor induksi.

\section{METODE PENELITIAN}

Pada bagian ini menjelaskan mengenai peningkatan sampling pada simulasi SVPWM discontinuous berbasis pembawa. Setelah menentukan metode yang digunakan, maka dilanjutkan dengan perancangan untuk menyimulasikan dan mengumpulkan data. Proses perancangan dan simulasi pada penelitian ini menggunakan perangkat lunak Quartus II.Rancangan dari metode SVPWM discontinuous terdiri dari beberapa rangkain projek pendukung diantaranya adalah: ajust, counter, v_beta_sin, v_alfa_cos, find sector, svm gen, dan deadtime. Peneliti tidak membuat semua rangkaian tersebut, melainkan menggunakan beberapa rangkaian yang sudah ada. Rangkaian yang dibuat peneliti yaitu rangkaian sinyal referensi yang terdiri dari v_beta_sin, v_alfa_cos dan counter.

\subsection{Desain sistem}

Rancangan dari metode SVPWM discontinuous terdiri dari beberapa rangkain projek pendukung diantaranya adalah: ajust, counter, v_beta_sin, v_alfa_cos, find sector, svm gen, dan deadtime. Peneliti tidak membuat semua rangkaian tersebut, melainkan menggunakan beberapa rangkaian yang sudah ada. Rangkaian yang dibuat peneliti yaitu rangkaian sinyal referensi yang terdiri dari v_beta_sin, v_alfa_cos dan counter yang berada dalam kotak hitam. Skema keseluruhan dari desain SVPWM discontinuous ditunjukkan berdasarkan Gambar 1.

Skema rangkaian yang dibuat oleh peneliti adalah counter, v_alfa_cos, dan v_beta_sin. Rangkaian counter yang sebelumnya 8 bit dibuat menjadi 9 bit, untuk rangkain v_alfa_cos dan v_beta_sin juga dibuat menjadi 9 bit dengan mengambil nilai pencuplikan 512 yang sebelumnya nilai pencuplikan 360 . 


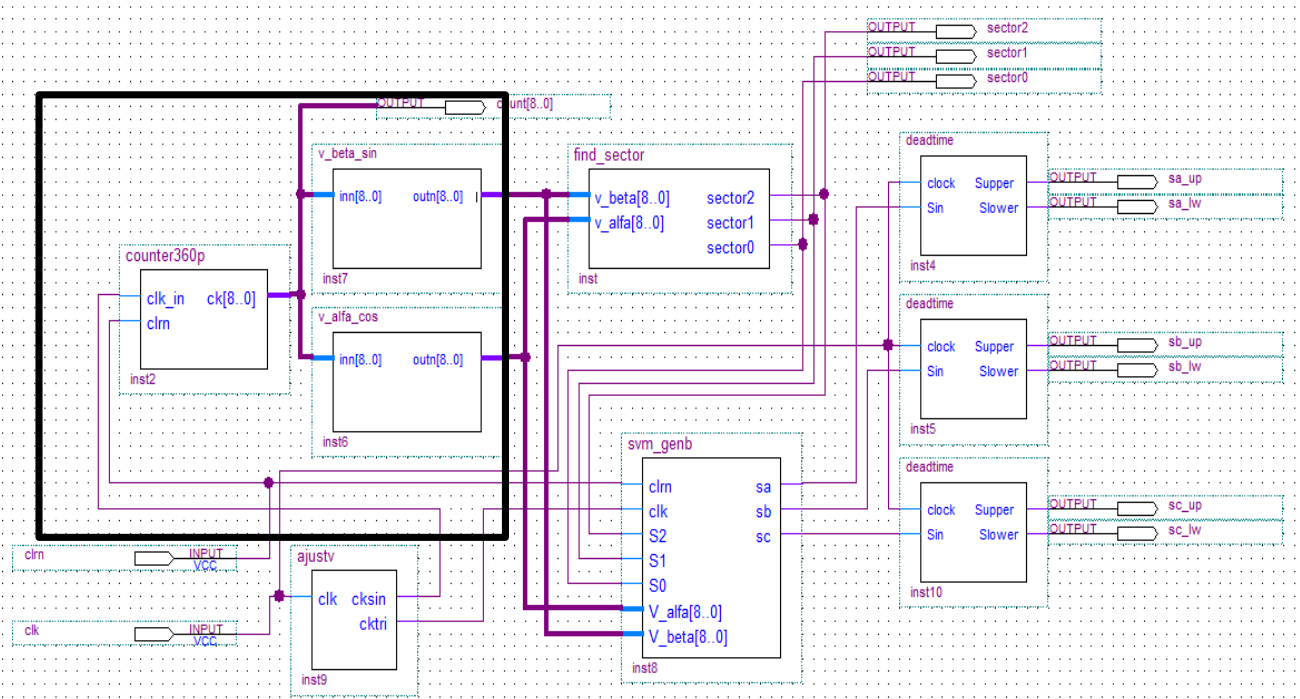

Gambar 1. Skema Keseluruhan dari Desain SVPWM Discontinuous

\subsection{Rangkaian Counter}

Rangkaian counter 9 bit ini tersusun dari 9 buah T Flip-flop. T Flip-flop merupakan rangkaian flip-flop yang telah dibuat dengan menggunakan flip-flop J-K yang kedua inputnya dihubungkan menjadi satu maka akan diperoleh flip-flop yang memiliki watak membalik output sebelumnya jika input tinggi dan output akan tetap jika input rendah. Dalam satu periode dibutuhkan cuplikan sebanyak 512 bagian, sehingga menggunakan cacahan dari 0-511 dan dibutuhkan pencacah mod-512. Rangkaian counter ini memperoleh dua masukan atau input, yaitu sinyal clock dan sinyal clear untuk mereset ulang cacahan setelah mencapai 511 untuk kembali ke 0. Keluaran dari rangkaian counter/ pencacah ini berupa cacahan 9 bit untuk mengambil data v_alfa_cos dan v_beta_sin. Rangkaian counter atau pencacah 9 bit ditunjukkan berdasarkan Gambar 2.

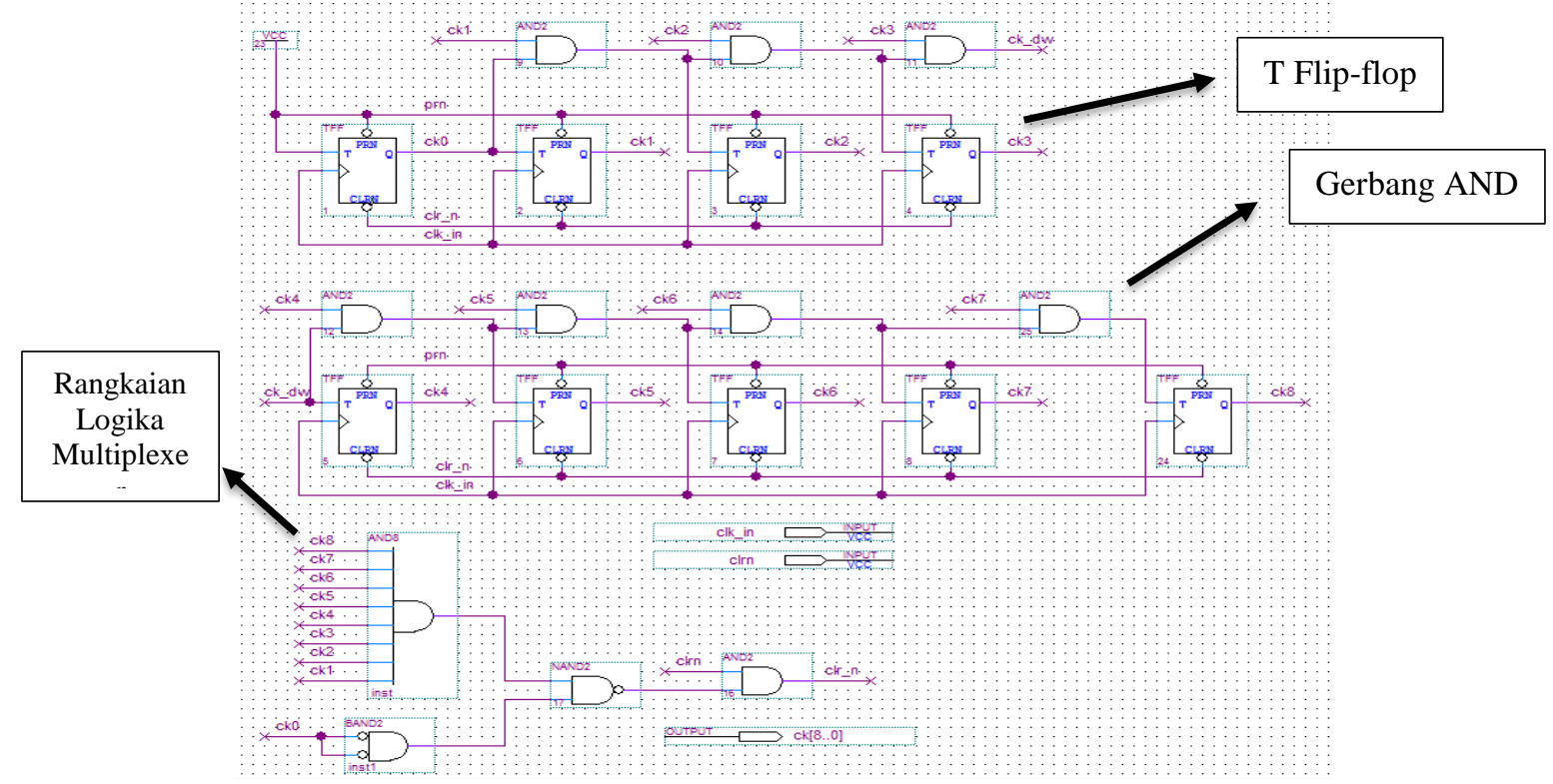

Gambar 2. Rangkaian Counter 9 bit Modolus 512

\subsection{Rangkaian $\mathbf{v} \_$beta_sin}

Rangkaian v_beta_sin dihasilkan melalui fungsi sinus dengan pemetaan memori 512 entri, karena dalam desain ini menggunakan 512 alamat pemetaan memori, maka akan menggunakan counter mod-512. Sebelum membuat rangkaian v_beta_sin pada text editor Quartus, terlebih dahulu dibuat nilai alamat sinus dan nilai keluaran memori sin. Nilai alamat sinus dibuat dari nilai 0 sampai 511 dalam angka biner karena untuk lebar pencuplikan 512. Nilai keluaran memori sinus diperoleh dengan suatu persamaan (1): 


$$
\operatorname{Memori} \operatorname{sinus}(y)=\sin \left(\frac{\operatorname{alamat}(x) * \text { satu periode sinus }}{\text { lebar pencuplikan }}\right)
$$

dengan, x bernilai 0 sampai 511, satu periode sinus adalah 360 dan lebar pencuplikan adalah 512.

Berdasarkan persamaan tersebut, dibuat nilai perhitungan keluaran memori sin. Hasil perhitungan nilai alamat dan nilai memori sin yang menggunakan persamaan (1) ditunjukkan berdasarkan Tabel 1. Nilai alamat dan nilai memori sin dibuat dalam bentuk biner agar lebih memudahkan untuk pengkodean pada text editor Quartus. Nilai alamat biner dibuat sebanyak 512 cuplikan mulai dari angka 0 hingga 511 yang diubah dalam bentuk biner sebesar 9 bit. Sedangkan nilai keluaran memori sinus dilakukan perhitungan menggunakan persamaan (1) diperoleh hasil berupa nilai positif dan negatif. Sehingga setelah nilai memori sinus (y) diubah ke bentuk biner maka ditambahkan satu bit depan sebagai bit tanda untuk bilangan tersebut bernilai positif atau negatif. Memori sinus (y) dibuat besarnya 9 bit, dengan bit depan sebagai bit signed dan 8 bit selanjutnya sebagai bit value. Setelah nilai alamat dan nilai memori sinus (y) diperoleh, maka dibuat program di text editor Quartus.

Tabel 1. Perhitungan Nilai Alamat Sinus(X) dan Nilai Memori Sinus(Y)

\begin{tabular}{|c|c|c|c|c|}
\hline $\begin{array}{c}\text { Nilai alamat } \\
\text { atau x } \\
\text { (desimal) }\end{array}$ & $\begin{array}{l}\text { nilai alamat atau } \\
\quad \mathrm{x} \text { (biner) }\end{array}$ & $\begin{array}{c}\mathrm{y} \text { atau } \\
\frac{\operatorname{Alamat}(x) * 360}{512}\end{array}$ & $\begin{array}{c}\text { nilai memori } \\
\text { sinus(y) (derajat) }\end{array}$ & $\begin{array}{l}\text { Nilai memori } \\
\text { sinus(y) (biner) }\end{array}$ \\
\hline 0 & 000000000 & 0 & 0 & 100000000 \\
\hline 1 & 000000001 & 0,703125 & 0,012271538 & 100000011 \\
\hline 2 & 000000010 & 1,40625 & 0,024541229 & 100000110 \\
\hline 3 & 000000011 & 2,109375 & 0,036807223 & 100001001 \\
\hline 4 & 000000100 & 2,8125 & 0,049067674 & 100001100 \\
\hline 5 & 000000101 & 3,515625 & 0,061320736 & 100001111 \\
\hline 6 & 000000110 & 4,21875 & 0,073564564 & 100010010 \\
\hline 7 & 000000111 & 4,921875 & 0,085797312 & 100010101 \\
\hline 8 & 000001000 & 5,625 & 0,09801714 & 100011001 \\
\hline 9 & 000001001 & 6,328125 & 0,110222207 & 100011100 \\
\hline 10 & 000001010 & 7,03125 & 0,122410675 & 100011111 \\
\hline$\ldots$ & $\ldots$ & $\cdots$ & $\ldots$ & $\ldots$ \\
\hline 511 & 111111111 & 359,296875 & 0,012271538 & 000000011 \\
\hline
\end{tabular}

\subsection{Rangkaian v_alfa_cos}

Rangkaian v_alfa_cos dihasilkan melalui fungsi cosinus dengan pemetaan memori 512 entri. Nilai alamat cosinus dibuat dari nilai 0 sampai 511 dalam angka biner karena untuk lebar pencuplikan 512. Nilai keluaran memori cosinus diperoleh dengan suatu persamaan sebagai berikut:

$$
\operatorname{Memori} \operatorname{sinus}(y)=\sin \left(\frac{\operatorname{alamat}(x) * \text { satu periode cosinus }}{\text { lebar pencuplikan }}\right)
$$

dengan x bernilai 0 sampai 511, satu periode sinus adalah 360 dan lebar pencuplikan sebsar 512. Berdasarkan persamaan tersebut, dibuat nilai perhitungan keluaran memori cosinus. Hasil perhitungan nilai alamat dan nilai memori cosinus yang menggunakan persamaan (2) ditunjukkan berdasarkan Tabel 2.

Tabel 2. Perhitungan Nilai Alamat Cosinus(X) dan Nilai Memori Cosinus(Y)

\begin{tabular}{|c|l|r|r|l|}
\hline $\begin{array}{c}\text { Nilai alamat } \\
\text { atau } x \\
\text { (desimal) }\end{array}$ & $\begin{array}{c}\text { nilai alamat atau } \\
\mathrm{x} \text { (biner) }\end{array}$ & $\frac{1}{\text { Alamat }(x) * 360}$ & \multicolumn{1}{c|}{$\begin{array}{c}\text { nilai memori } \\
\text { cosinus(y) (derajat) }\end{array}$} & $\begin{array}{c}\text { Nilai memori } \\
\text { cosinus(y) } \\
\text { (biner) }\end{array}$ \\
\hline 0 & 000000000 & 0 & 1 & 100000000 \\
\hline 1 & 000000001 & 0,703125 & 0,999924702 & 111111111 \\
\hline 2 & 000000010 & 1,40625 & 0,999698819 & 111111111 \\
\hline
\end{tabular}




\begin{tabular}{|c|l|r|r|r|}
\hline $\begin{array}{c}\text { Nilai alamat } \\
\text { atau } \\
(\text { desimal })\end{array}$ & $\begin{array}{c}\text { nilai alamat atau } \\
\text { x (biner) }\end{array}$ & $\frac{1}{\text { Alamat }(x) * 360}$ & \multicolumn{1}{c|}{$\begin{array}{c}\text { nilai memori } \\
\text { cosinus(y) (derajat) }\end{array}$} & $\begin{array}{c}\text { Nilai memori } \\
\text { cosinus(y) } \\
\text { (biner) }\end{array}$ \\
\hline 3 & 000000011 & 2,109375 & 0,999322385 & 111111111 \\
\hline 4 & 000000100 & 2,8125 & 0,998795456 & 111111111 \\
\hline 5 & 000000101 & 3,515625 & 0,998118113 & 111111111 \\
\hline 6 & 000000110 & 4,21875 & 0,997290457 & 111111111 \\
\hline 7 & 000000111 & 4,921875 & 0,996312612 & 111111111 \\
\hline 8 & 000001000 & 5,625 & 0,995184727 & 111111110 \\
\hline 9 & 000001001 & 6,328125 & 0,99390697 & 111111110 \\
\hline 10 & 000001010 & 7,03125 & 0,992479535 & 111111110 \\
\hline$\ldots$ & $\ldots$ & $\ldots$ & $\ldots$ & $\ldots$ \\
\hline 511 & 11111111 & 359,296875 & 0,999924702 & 11111111 \\
\hline
\end{tabular}

\section{HASIL DAN PEMBAHASAN}

Setelah melakukan perancangan rangkaian menggunakan perangkat lunak Quartus II 8.0, diperoleh hasil pengamatan berupa sinyal keluaran yang dihasilkan dari simulasi rangkaian pada perangkat lunak. Simulasi pada perangkat lunak Quartus II dilakukan pada setiap unit pembangun rangkaian SVPWM dan juga simulasi untuk keseluruhan rangkaian.

\subsection{Simulasi Unit V_Beta_Sin}

Simulasi dari unit v_beta_sin telah berhasil dilakukan dengan menggunakan perangkat lunak Quartus II dan tidak terdapat error. Total logic elements sebesar 168 dari 33.216 atau kurang dari 1\%, total pin 18 dari 475 atau 4\%, total bit memori 0\% dan total PLLs 0\%. Karena ukuran bit memori dan PLLs dari projek Rangkaian v_beta_sin yang sangat kecil sehingga nilainya $0 \%$. Hasil dari simulasi unit v_beta_sin seperti yang ditunjukkan pada Gambar 3.

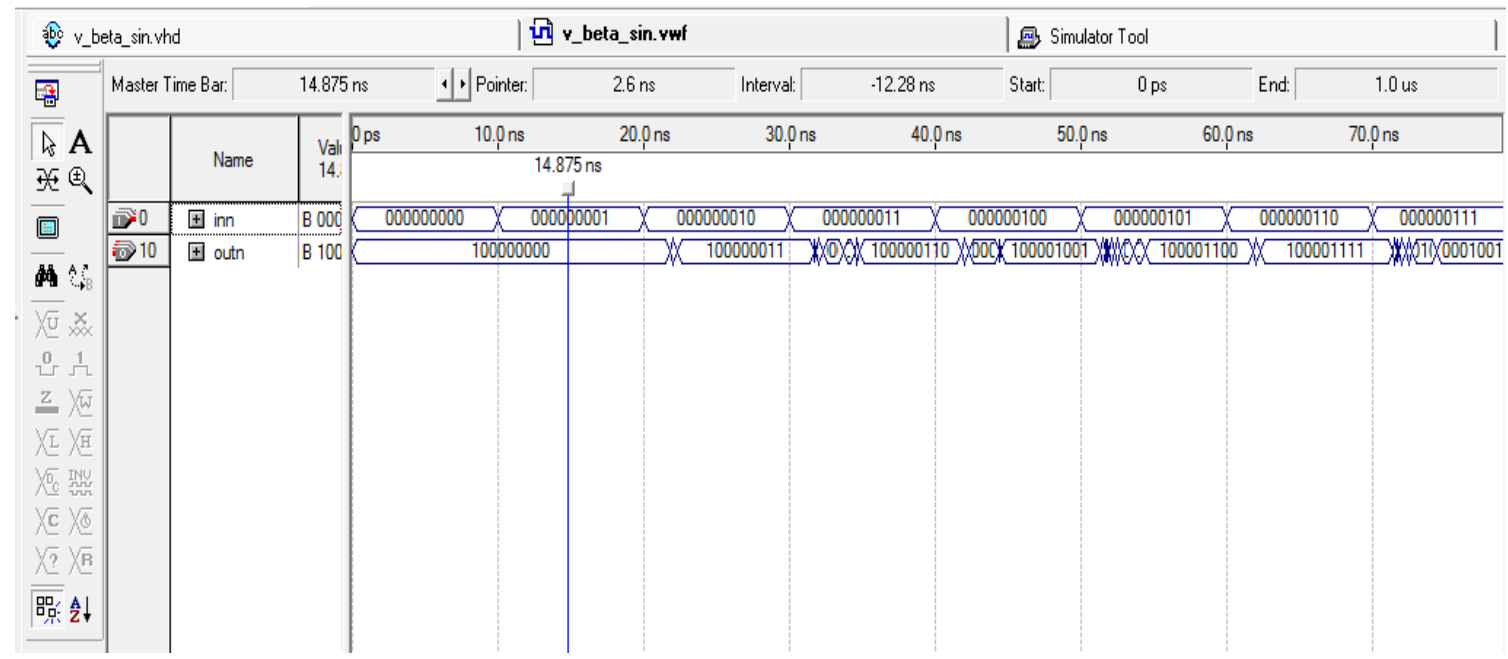

Gambar 3. Hasil Kompilasi Unit v_beta_sin

Hasil simulasi unit v_beta_sin yang ditampilkan telah sesuai dengan rancangan program yang telah dibuat. Hasil input dan output ditampilkan dalam bilangan biner, jika input 000000000 maka output 100000000, jika input 000000001 output 100000011 dan seterusnya sampai alamat 511. Hasil simulasi yang ditunjukkan sesuai dengan perhitungan nilai alamat sinus dan nilai memori sinus yang berada dalam tabel sebelumnya. Dari hasil simulasi tersebut unit v_beta_sin dapat digunakan sebagai rangkain pendukung untuk peningkatan sampling pada simulasi SVPWM discontinuous berbasis pembawa. 


\subsection{Simulasi Unit V_Alfa_Cos}

Proses simulasi unit $\mathrm{v}$ _alfa_cos sama dengan proses kompilasi unit v_beta_sin. Simulasi dari unit v_alfa_cos telah berhasil dilakukan dengan menggunakan perangkat lunak Quartus II dan tidak terdapat error. Total logic elements sebesar 171 dari 33.216 atau kurang dari 1\%, total pin 18 dari 475 atau 4\%, total bit memori 0\% dan total PLLs 0\%. Hasil simulasi seperti yang ditunjukkan oleh Gambar 4.

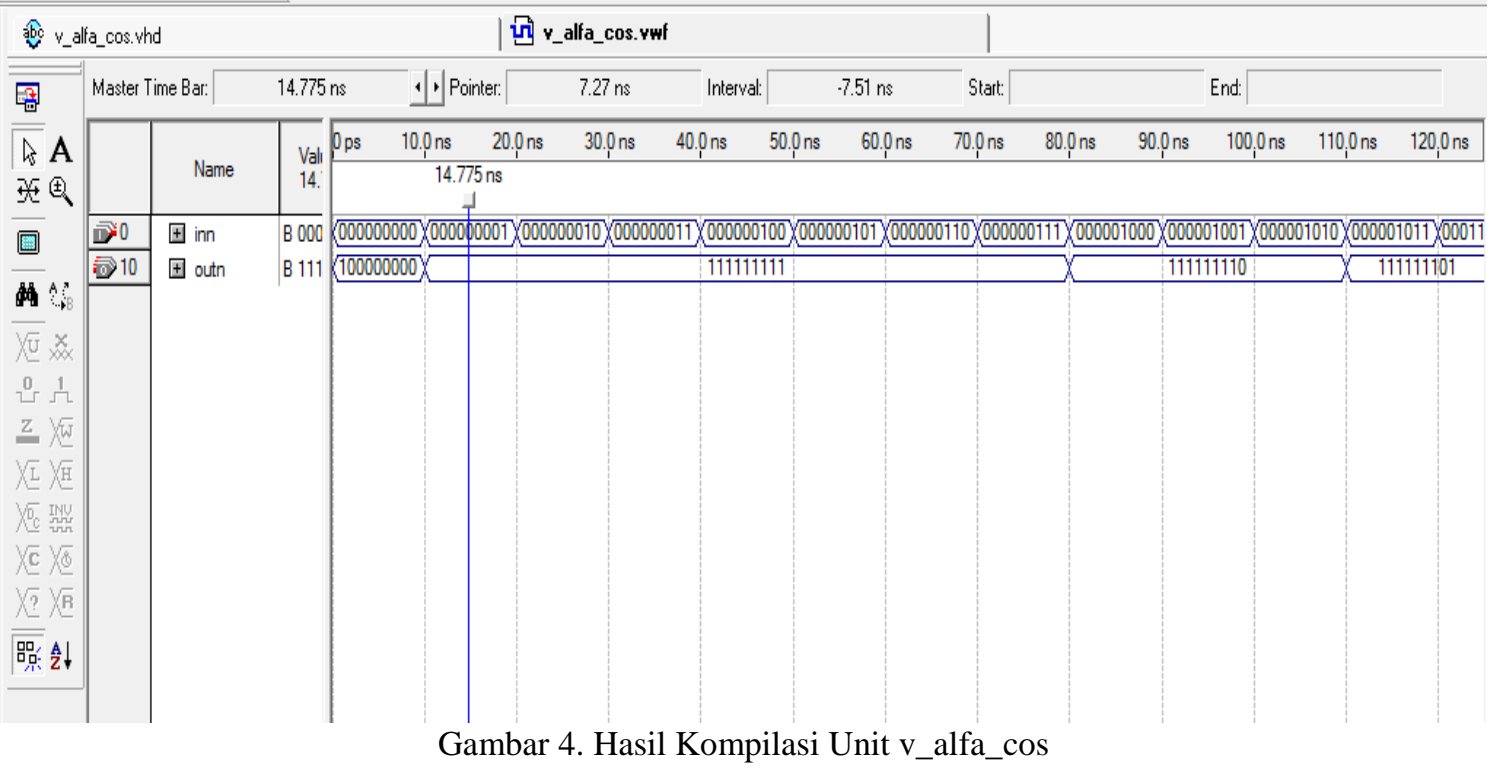

Hasil input dan output ditampilkan dalam bilangan biner, ketika input 000000000 maka output 100000000 , ketika input 000000001 output 111111111 dan seterusnya sampai alamat 511. Hasil simulasi yang ditunjukkan sesuai dengan perhitungan nilai alamat cosinus dan nilai memori cosinus yang berada dalam tabel sebelumnya. Dari hasil simulasi tersebut unit v_beta_sin dapat digunakan sebagai rangkain pendukung untuk peningkatan sampling pada simulasi SVPWM discontinuous berbasis pembawa.

\subsection{Simulasi Unit Pencacah atau Counter}

Unit pencacah atau counter yaitu unit yang berfungsi sebagai penghasil cacahan untuk mengambil data. Dalam satu periode pengambilan data diperlukan 512 cacahan, setelah selesai membuat projek atau program maka dilakukan kompilasi dan dilanjutkan dengan melakukan simulasi untuk mengetahui hasil dari program yang telah dibuat pada perangkat lunak Quartus. Hasil simulasi unit pencacah atau counter ditunjukkan pada Gambar 5.

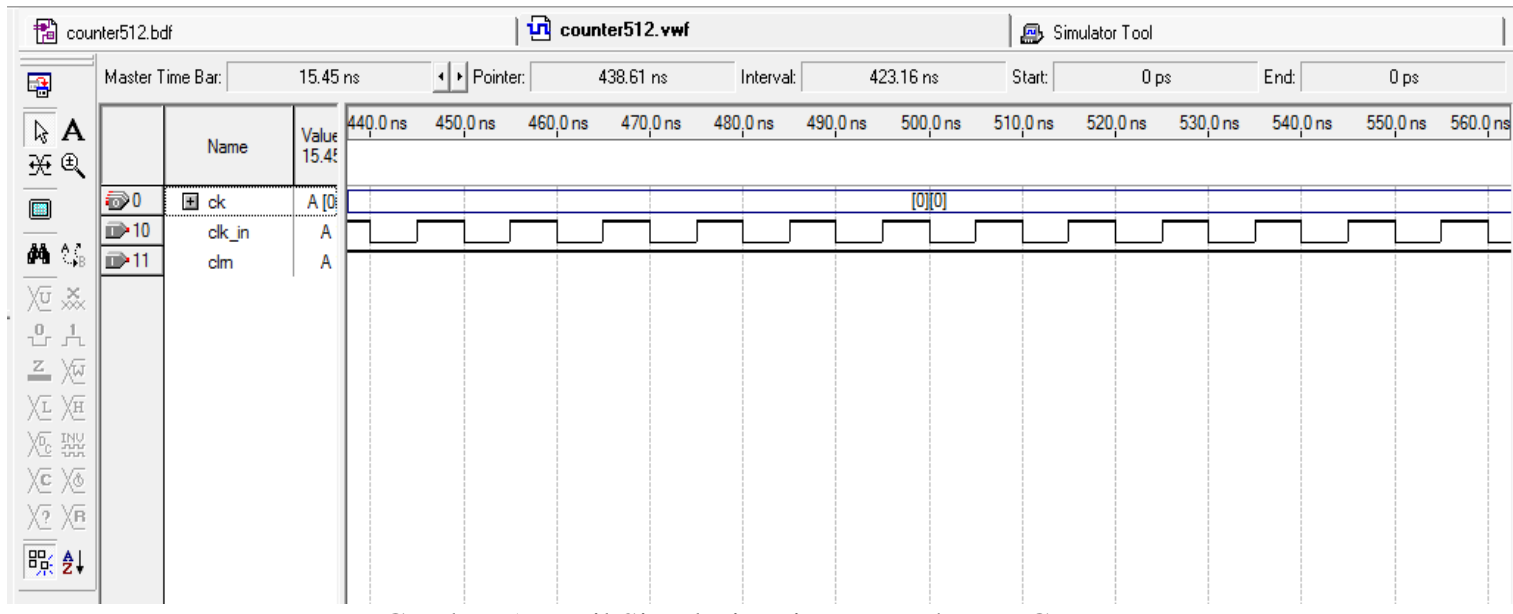

Gambar 5. Hasil Simulasi Unit Pencacah atau Counter

Hasil simulasi unit counter yang ditampilkan telah sesuai dengan rancangan program yang telah dibuat. Rangkaian counter ini terdapat 2 masukan atau input yaitu berupa sinyal clock dan sinyal clear untuk mereset 
ulang cacahan setelah mencapai 511 untuk kembali ke 0. Dari hasil simulasi tersebut unit counter dapat digunakan sebagai rangkaian pendukung untuk peningkatan sampling pada simulasi SVPWM discontinuous berbasis pembawa.

\subsection{Simulasi Metode SVPWM Secara Keseluruhan}

Setelah semua projek pendukung dirangkai, kemudian dilakukan proses kompilasi. Proses kompilasi telah berhasil dilakukan dengan menggunakan total logic elements (Les) sebesar 1635 dari 33216 atau sebesar 5\%. Total register yang digunakan sebesar 163 dan total pin terpakai 23 dari 475. Hasil simulasi peningkatan sampling SVPWM discontinuous telah berhasil seperti yang ditunjukkan pada Gambar 6.

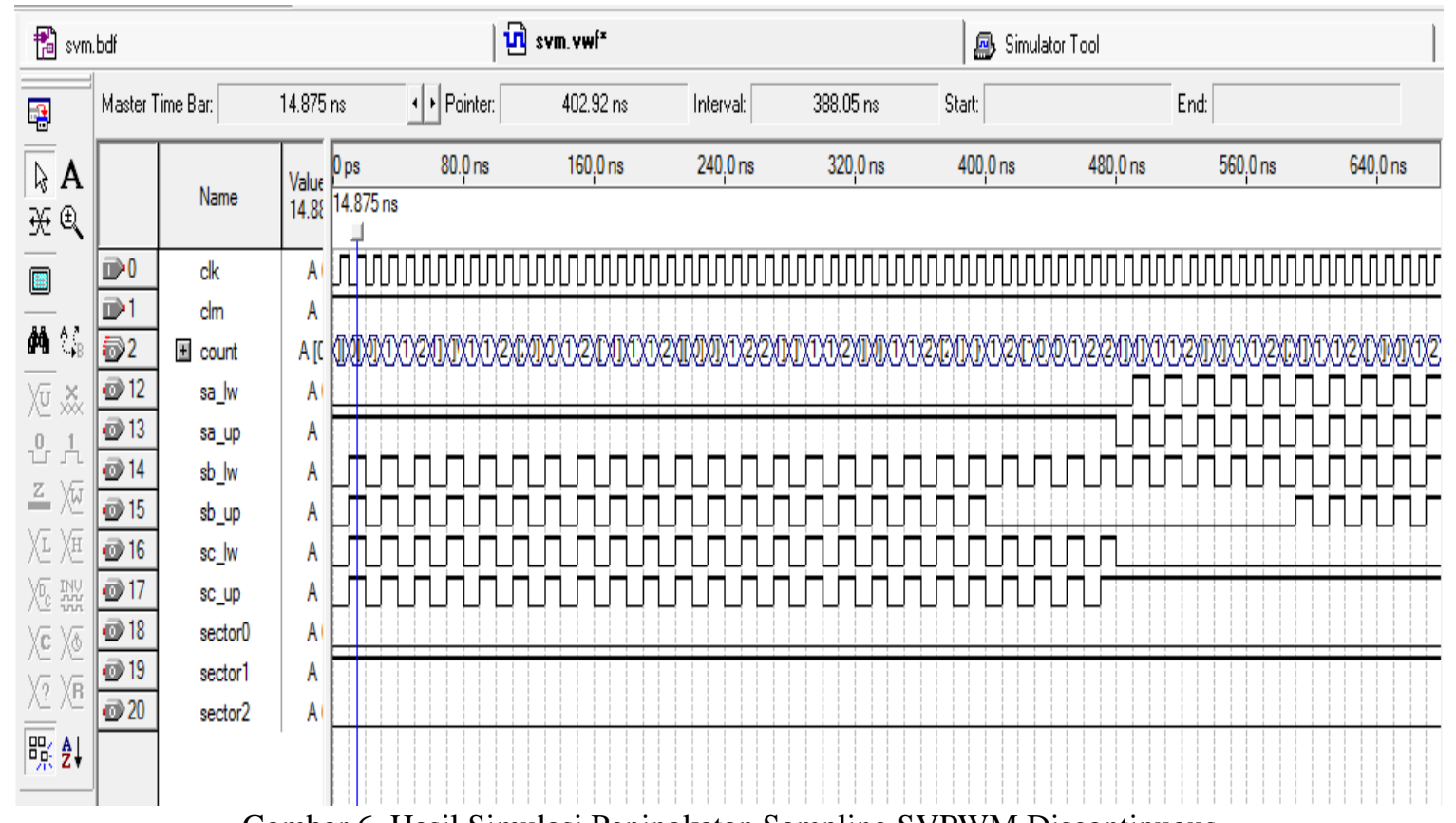

Gambar 6. Hasil Simulasi Peningkatan Sampling SVPWM Discontinuous

Sinyal keluaran dari simulasi metode SVPWM secara keseluruhan telah berhasil disimulasikan menggunakan perangkat lunak Quartus II, dan berhasil meningkatkan sampling dari penelitian sebelumnya yang 360 menjadi 512.

\section{KESIMPULAN}

Rangkaian unit v_beta_sin, dan unit v_alfa_cos sebagai masukkan sinyal referensi telah berhasil disimulasikan dan dapat digunakan sebagai rangkaian pendukung pada simulasi metode SVPWM discontinuous. Peningkatan sampling yang diusulkan pada simulasi SVPWM discontinuous adalah sebesar 512.

\section{UCAPAN TERIMA KASIH}

Sampaikan ucapan terima kasih kepada editor dan reviewer atas saran, masukan serta bantuan dalam penerbitan naskah. Ucapan terima kasih juga ditunjukkan kepada pihak-pihak yang telah mendukung penelitian.

\section{REFERENSI}

[1] B. A. Yomahudaya and T. Sutikno, "Pembangkit Sinyal SPWM untuk Multilevel Inverter Satu Fasa Lima Tingkat Berbasis Mikrokontroler At-Mega32," Jurnal Ilmu Teknik Elektro Komputer dan Informatika, vol. 3-2, pp. 73-81, 2017. DOI: $10.26555 /$ jiteki.v3i2.5927

[2] Z. G. Wang, et al., "SVPWM Techniques and Applications in HTS PMSM Machines Control," Journal Of Electronic Science And Technology Of China, vol. 6-2, pp. 191-197, 2008.

[3] T. Sutikno, A. Jidin, N. R. N. Idris, "New approach FPGA-based implementation of discontinuous SVPWM," Turk J Elec Eng \& Comp Sci, vol. 18, no. 4, 2010. DOI: 10.3906/elk-0906-21

[4] A. Belkheiri, S. Aoughellanet and M. Belkheiri, "FPGA Implementation of a Space Vector Pulse Width Modulation Technique for a Two-Level Inverter," Elektrotehniški Vestnik, vol. 85, no. 3, pp. 1-7, 2018. Online

[5] T. Sutikno, W. J. Hwa, A. Jidin and N. R. N. Idris "A Simple Approach of Space-vector Pulse Width Modulation Realization Based on Field Programmable Gate Array," Electric Power Components and Systems, vol. 38, pp. 15461557, 2010. DOI: $\underline{10.1080 / 15325008.2010 .482092}$ 
[6] B. Rashidi and M. Sabahi, "High Performance FPGA Based Digital Space Vector PWM Three Phase Voltage Source Inverter," I.J.Modern Education and Computer Science, vol. 1, pp. 62-71, 2013. DOI: 10.5815/ijmecs.2013.01.08

[7] T. Sutikno, A. Jidin, and M. F. Basar, "Simple Realization of 5-Segment Discontinuous SVPWM Based on FPGA," International Journal of Computer and Electrical Engineering, vol. 2-1, pp. 1793-8163, 2010. Online

[8] T. Sutikno, N. R. N. Idris, A. Jidin, M. H. Jopri, "FPGA Based Optimized Discontinuous SVPWM Algorithm for Three Phase VSI in AC Drives," International Journal of Power Electronics and Drive System, vol. 3-2, pp. 228240, 2013. DOI: $10.11591 /$ ijpeds.v3i1.735

[9] M. A. Khan and A. Iqbal, A. R. Haitham "Investigation of Discontinuous Space Vector PWM Techniques of a Threephase Voltage Source Inverter," i-manager's Journal on Electrical Engineering, vol. 2-3, pp. 60-71, 2009. Online

[10] M. A. Khan, A. Iqbal, Sk M. Ahmad, Z. husain "Analysis of Discontinuous Space Vector PWM Techniques for a Seven-Phase Voltage Source Inverter," International Journal of Power Electronics and Drive System, vol. 2-2, pp. 203-218, 2012. Online

\section{BIOGRAFI PENULIS}

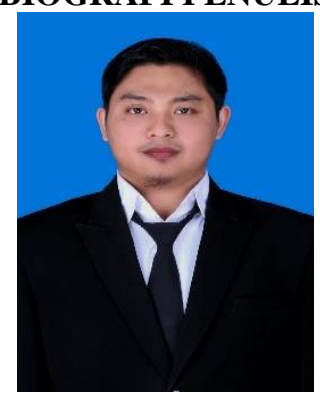

\section{Okik Surikno}

Lahir di Lamongan, 02 juli 1994, telah menyelesaikan program studi S1 Teknik Elektro di Universitas Ahmad Dahlan angkatan tahun 2013 dan telah menyelesaikan pendidikan tersebut pada tahun 2019 bidang peminatannya adalah Otomasi Industri.

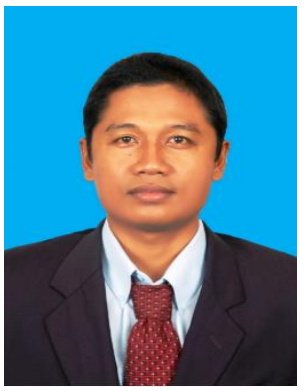

\section{Tole Sutikno}

Lahir di Lamongan, 12 juli 1975, beliau telah menyelesaikan kuliah S1 Teknik Elektro di UNDIP Semarang, S2 Teknik Elektro di UGM Yogyakarta dan S3 Teknik Elektro di UTM Malaysia. Beliau adalah Dosen di Program Studi Teknik Elektro, Fakultas Teknologi Industri, Universitas Ahmad Dahlan Yogyakarta. 